apuntesuniversitarios.upeu.edu.pe

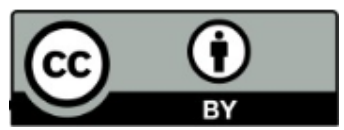

Apuntes Universitarios, 2021: 11(2), abril-junio ISSN:

2304-0335 DOI: https://doi.org/10.17162/au.v11i2.657

\title{
La mediación de la satisfacción laboral en la relación del estilo de liderazgo y el compromiso organizacional
}

\author{
The mediation of labor satisfaction in the relationship of the leadership style and \\ organizational commitment
}

María Auxiliadora Guerrero-Bejarano ${ }^{1 a}$; Carlos Manosalvas-Vaca ${ }^{2}$; Claribel Rosario SalvadorGarcía $^{3}$; Ima Milagros Carhuancho-Mendoza ${ }^{4}$; Aldo Alfredo Maino Isaías ${ }^{5}$

; Daniel Ricardo Silva Siu ${ }^{6}$

Universidad Internacional del Ecuador, Guay
Universidad Estatal Amazónica de Ecuador,
Universidad César Vallejo, Lima, P
Universidad Privada Norbert Wiener, L
(iD) ORCID: $0000-0002-1412-5870^{1}$
(iD) ORCID: $0000-0002-7521-069 \mathrm{X}^{2}$
(iD) ORCID: 0000-0002-2147-3259
(iD) ORCID: $0000-0002-4060-5667^{4}$
(iD) ORCID: $0000-0003-4054-1461^{5}$
(iD) ORCID: $0000-0003-1783-6261^{6}$

Recibido: 30 de agosto de 2020

Aceptado: 04 de febrero de 2021

\begin{abstract}
The objective of this work was to determine the relationship between job leadership style and job satisfaction, and how this relationship affects organizational commitment; using the leadership theory of Bass and Avolio, through the MLQ questionnaire. The organizational commitment was measured with the tool generated from the Meyer and Allen theory and job satisfaction with the Paul Spector questionnaire. The study was outlined with the theoretical basis of the quantitative approach, deductive, cross-sectional method. Data collection was carried out through the survey with the respective questionnaire for each variable, the sampling was for convenience, and 386 people participated voluntarily. Data were analyzed with an SEM model. The results show that the data have a good fit according to the Chicuadrado test; in addition, convergent and divergent validity was performed. Therefore, in Ecuadorian reality it was shown that transformational leadership is related to job satisfaction $(\mathrm{r}=.55, \mathrm{p}<0.05)$, while transactional leadership is negatively related to satisfaction $(r=-.154, \mathrm{p}<0.05)$. However, transactional leadership is not
\end{abstract}


related to organizational commitment ( $p>0.05$ ), and job satisfaction influences organizational commitment $(\mathrm{r}=.608, \mathrm{p}<0.05)$. The results obtained in the ecuadorian culture prove results of previous studies carried out in other cultures, the transformational leadership style has a positive impact on job satisfaction and organizational commitment, while the transactional leadership style would have a negative impact with the other variables studied.

Keywords: Job satisfaction, organizational commitment, leadership, people management, work management

\section{Resumen}

El objetivo de este trabajo fue determinar la relación entre el estilo de liderazgo laboral y la satisfacción laboral, y cómo esta relación afecta el compromiso organizacional; utilizando la teoría del liderazgo de Bass y Avolio, a través del cuestionario MLQ. El compromiso organizacional se midió con la herramienta generada a partir de la teoría de Meyer y Allen y la satisfacción laboral con el cuestionario de Paul Spector. El estudio se diseñó sobre la base teórica del enfoque cuantitativo, deductivo, método transversal. La recolección de datos se realizó a través de la encuesta con el respectivo cuestionario para cada variable, el muestreo fue por conveniencia y 386 personas participaron de manera voluntaria. Los datos se analizaron con un modelo SEM. Los resultados muestran que los datos tienen un buen ajuste según la prueba de Chicuadrado; además, se realizó validez convergente y divergente. Por tanto, en la realidad ecuatoriana se demostró que el liderazgo transformacional se relaciona con la satisfacción laboral $(\mathrm{r}=.55, \mathrm{p}<0.05)$, mientras que el liderazgo transaccional se relaciona negativamente con la satisfacción $(r=-.154, p<0.05)$. Sin embargo, el liderazgo transaccional no está relacionado con el compromiso organizacional (p> 0.05) y la satisfacción laboral influye en el compromiso organizacional $(\mathrm{r}=.608, \mathrm{p}<0.05)$. Los resultados obtenidos en la cultura ecuatoriana demuestran resultados de estudios previos realizados en otras culturas, el estilo de liderazgo transformacional tiene un impacto positivo en la satisfacción laboral y el compromiso organizacional, mientras que el estilo de liderazgo transaccional tendría un impacto negativo con las demás variables estudiadas.

Palabras clave: satisfacción laboral, compromiso organizacional, liderazgo, gestión de personas, gestión del trabajo

\section{Introduction}

Human behavior within companies is undoubtedly one of the most studied variables due to the previous evidence that has shown the impact it has on their performance. In addition to its ability to survive over time, the organizational commitment, which is defined as the desired behavior among workers. It is one of the most important but also the most difficult to achieve. According to a study, only $13 \%$ of workers are committed to the company they work in (Bersin, Agarwal, Pelster y Schwartz, 2015) constituting the biggest challenge of bosses or business leaders. 
The majority of studies of this type carried out in recent years were carried out in European or Anglo-Saxon countries. This work sought to contribute by expanding research to Latin America, specifically to Ecuador, to check if the results obtained previously resemble a different cultural reality (Robbins, Judge, Millett y Boyle, 2013; Shanker, 2016; Shrama y Bajpai, 2010).

We sought to understand the behavior of service companies in Ecuador due to the growth and importance of the industry for the generation of welfare. The permanent crises that affect the countries have generated changes in the markets that are increasingly composed of serviceoriented companies, even when they continue to produce products. Globalization has forced companies to seek better levels of competitiveness and service (Bejarano, 2018; Chib, 2016; Garcia-Almeida, Fernández-Monroy y Saá-Pérez, 2015; Quintana, Park y Cabrera, 2015; Shanker, 2016); to return customers to consume their products, which generates higher profitability (Bejarano, 2018; Chib, 2016; García-Almeida, Fernández-Monroy y Saá-Pérez, 2015; Quintana, Park y Cabrera, 2015; Shanker, 2016). Human resources play an essential role in this goal. Their level of commitment is related to their level of performance (Chen, Lyu, Li, Zhou y Li, 2017; Pantouvakis y Bouranta, 2013b).

Cultural aspects would also influence human behavior in collectivist cultures, for example, people consider financial security more important than individual well-being (Appelbaum, Louis, Makarenko, Saluja, Meleshko y Kulbashian, 2013; Van Der Wethuizen, Pacheco y Webber, 2012).

In Ecuador, $77.3 \%$ of companies depend in some way on customer service (INEC, 2014), despite this, the companies affected by this item do not have good results in general, which does not allow generating greater well-being in the country (Daude y Fernández-Arias, 2010; Ordoñez, 2011; Rucalcaba, Gago, Ariano y Tripathi, 2016).

The aforementioned has, as a consequence, that despite being an item that generates millions of jobs has a negative result in their balance, they are companies that fail to take advantage of their importance and fail to have efficiency levels that allow them to be more profitable (Falconí, 2015).

Hofstede (1983) classifies Ecuador as a country of a collectivist culture, that is to say, that it would have great distances of power and active avoidance of uncertainty. Those mentioned above would mean that in order for an organization to be successful, it must be a collective concern 
for employees, which implies a concern for organizational culture. It should be noted that the results obtained by the heads of groups are also affected by the national culture (Hofstede, 1983; Al-Laymoun, 2017; Jha y Pandey, 2015). This study seeks to show if the transactional leadership style has a better or equal performance than the transformational leadership style in employee satisfaction and then if these relationships affect the level of present commitment.

\section{Leadership styles}

For this work, the proposal by Bass and Avolio (1990) that classify leadership into three transactional, transformational, and laisse faire styles were chosen from among the different leadership theories. This theory is one of the most studied and accepted for some decades, to measure this variable, the authors created the Multifactor Leadership Questionnaire (MLQ), which has been translated into different languages and validated in previous studies (Alonso, Sabiya y Guirado, 2010).

Theoretically, transformational leadership is considered to encourage personal and professional development in workers, as well as organizational principles, bosses who apply these types of styles are usually aware of what the company's goals are and motivate teamwork for achievement of objectives (Bass y Avolio, 2003; Bass y Avolio, 1994; Wang y Howell, 2010). Transformational leaders often challenge their followers by understanding their needs, which can generate innovation in the way they solve their problems (Jain, 2016).

That the leaders had a relationship of rewards with their followers was what was customary, for the theory mentioned, this type of interaction is defined as transactional leadership that is based on the compensation of the achievements obtained by the workers that can result in levels of well-being in workers and better performance when applied correctly (Bass, 1988). The transactional leader sets the goals of his team and how they will be compensated. It must be clear when defining it, to ensure compliance, which becomes vital for the success of the model. Another critical factor is the knowledge of the skills of the members of their teams to establish the challenges properly, understanding that the focus of these leaders is the result obtained by their team, not their personal development (Avolio, Bass y Jung, 1999; Bass, 1985; Bycio, Hackett y Allen, 1995; Xirasagar, 2008; Yahaya, Ebrahim y Sheard, 2016).

The MLQ questionnaire is made up of six dimensions, divided between the three styles (Bass, 1985) the transformational leadership represented by (a) the charism; (b) intellectual stimulation and, (c) individualized consideration. Transactional leadership: (d) contingent reward 
and (e) administration by active exception; laisse faire represented by (f) passive avoidance leadership (Avolio, Bass y Jung, 1999).

This study sought to establish whether there are differences due to the type of style that the bosses apply with their work teams and the effect that this has on the perception of well-being at work, that is, job satisfaction. Previous studies show a positive relationship between these variables (Ali, Sidow y Guleid, 2013; Arzi y Farahdob, 2014; Bass, Avolio, Jung y Berson, 2003; Cardona, 2000; Guerrero, Añazco, Valdivieso y Sánchez, 2018; Quintana, Park y Cabrera, 2015). Other studies have resulted in differences in styles and their impact on satisfaction due to other factors such as national culture, organizational, type of company, and the climate of the same (Bass, 1997; Hussain y Riaz, 2010; Politis, 2002; Vigoda-Gadot, 2007). According to Bass (1988), the transactional leader can achieve positive results using his appropriate style, and the transformational creates an environment of desirable commitment in companies. Other works that have compared the two styles have found in their results that the Transformational leadership could obtain better results when obtaining low staff turnover rates, higher job satisfaction and better performance (Armanddi, Oppedisano y Sherman, 2003; Arzi y Farahdob, 2014; Bartram y Casimir, 2007; Bhatti, Maitlo, Shaikh, Hashmi y Shaikh, 2013; Braun, Peus, Weisweiler y Frey, 2013; Hussain y Riaz, 2010; Yaghoubipoor, Tee y Ahmed, 2013; Zhao, Ghiselli, Law y Ma, 2016).

In this case, the national culture is a factor that influences the level of influence of the leadership style in aspects such as satisfaction, according to various studies this would allow affirming that no style can be considered superior to another in all cases, the two styles in different Studies have yielded positive results with different variables such as job satisfaction (Hussain y Riaz, 2010; Vigoda-Gadot, 2007; Avolio, Bass y Jung, 1999; Yiing y Ahmad, 2009). The type of company is also a factor that affects this relationship (Nawaz, 2010). In this work, two dependent variables were identified, the job satisfaction that is defined as an emotional state that affects the employee's performance in the company, and the Organizational Commitment that is defined as an attitude of the worker towards the organization (Gyamfi, 2014).

\section{Job Satisfaction}

Satisfaction is also defined as the worker's taste feels with his work, and it is affirmed that he has a positive relationship with his well-being (Bandura y Lyons, 2014; Locke, 1976; Spector, 1997). Some previous work proved that job satisfaction influences the level of performance of companies, defining that satisfied employees can satisfy customers. Likewise, generates better 
levels of profitability (Bejarano y Siu, 2017; Gounaris y Boukis, 2013; Khalilzadeh, Chiappa, Jafari y Borujeni, 2013; Pantouvakis y Bouranta, 2013a; Zumrah y Boyle, 2015).

Factors such as gender and age influence employee satisfaction, making it easier to satisfy older employees than by their levels of responsibility. They may feel satisfied in a stable work environment, while younger generations look for jobs that generate more significant challenges. In terms of gender, for women in general, salary is one of the most critical dimensions of satisfaction, while for men, recognition (El Badawy y Magdy, 2015; Maamari, 2014; Saner y Sadikoglu, 2016; Vetráková y Mazúchová, 2015).

This study has taken the satisfaction questionnaire developed by Spector (1985) that establishes three main dimensions of satisfaction: (a) participation in decision making; (b) organizational identification; and (c) the relationship between the employee and the leader (PujolCols y Dabos, 2018), this questionnaire has been translated and validated by its author in several languages and culture.

\section{Organizational commitment}

The organizational commitment is the link that affects the permanence in the companies of the employees, models their way of doing things, and decreases levels of rotation of the human resource. It is a desired attitude for entrepreneurs but challenging to achieve (Ahluwalia y Preet, 2017; Cohen, 2007; Jernigan, Beggs y Kohut, 2002; Kuo, 2013; Meyer, Samley, Hercovich y Topolnytky, 2002; Shanker, 2016). A high level of organizational commitment affects the company's performance and how this effect produces better work climates, better willingness to change and to the proper management of knowledge, as well as its generation (Shanker, 2016; Karim y Rehman, 2012; Meyer y Herscovitch, 2001; Shurbagi, 2014; Feinstein, Vondradesk, Martin, Ogawa, Dalbor, Stefanelli y Cannon, 2001).

Cultures and types of companies also affect the level of organizational commitment within companies, for example, public companies tend to provide greater security among employees, which generates a higher level of commitment in employees; Age, level of education and time at work also influence this variable (Mahanta, 2012; Mathieu y Zajac, 1990; Savery y Syme, 1996; Meyer y Allen, 1991).

Some studies have shown that the level of commitment is low in most companies despite its importance, so this study aims to understand what affects it (Bersin, Agarwal, Pelster y 
Schwartz, 2015). The instrument used to measure organizational commitment corresponds to the one defined based on the theory of Meyer \& Allen (1991), which divides it into three dimensions: (a) active commitment, (b) the commitment to continuity, and (c) the normative commitment (Jha y Pandey, 2015).

Because leadership does not directly affect organizational commitment, job satisfaction served a double function, in addition to being a dependent variable, it was a mediator for the relationship between leadership style and organizational commitment, in the same way, national culture (Keller, 2006; Walumbwa, Lawler y Avolio, 2007; Slocum y Hellriegel, 2009). National culture politically and sociologically affects decision-making in companies, which also influences the styles of leadership applied and the results obtained (Hofstede, 1983). The main objective of this work was to relate the variables explained by identifying in the literature the existing relationships and how the variables defined in the model can affect them (Robbins, Judge, Millett y Boyle, 2013; Feinstein, Vondradesk, Martin, Ogawa, Dalbor, Stefanelli y Cannon, 2001; Vujičić, Jovičić, Lalić, Gagić y Cvejanov, 2015; Bushra, Usman y Naveed, 2011) is shown in Figure 1.

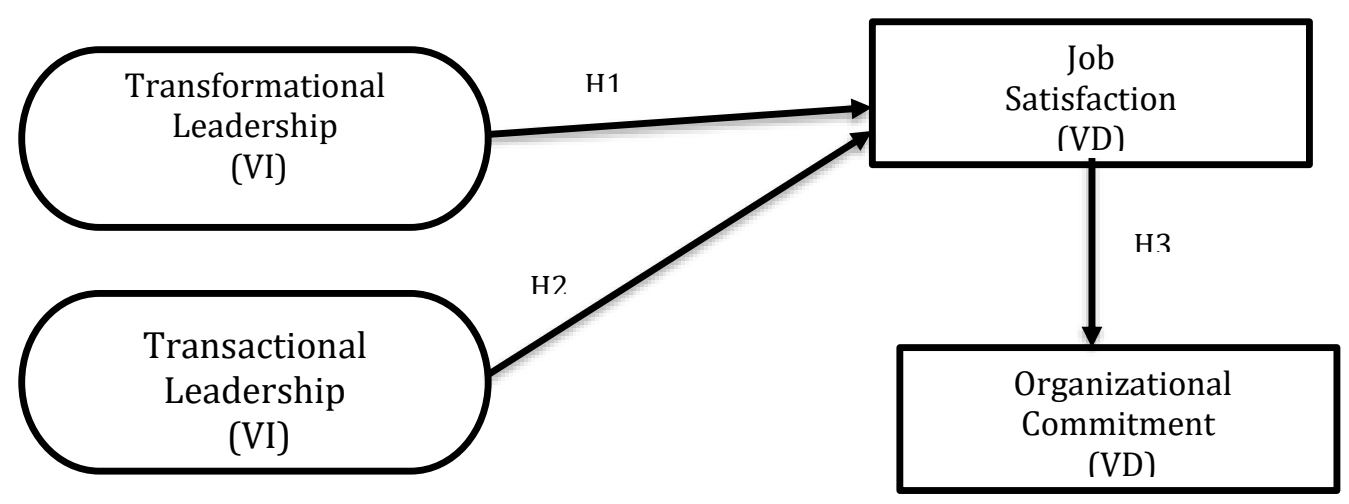

Figure 1. A proposed conceptual framework

The questions that were sought to answer in this study a) To what extent does the style of transactional leadership relate to the level of job satisfaction present in service companies within the context of a collectivist culture? B) To what extent does the transformational leadership style relate to the level of job satisfaction present in service companies within the context of a collectivist culture? C) To what extent are job satisfaction and organizational commitment related to service companies, within the context of a collectivist culture? These questions individually generated the following hypotheses: 
$\mathrm{H} 1$ : In collectivist cultures, there is a positive relationship between the style of transactional leadership and the level of job satisfaction present in service companies.

$\mathrm{H} 2$ : In collectivist cultures, there is a positive relationship between the transformational leadership style and the level of job satisfaction present in service companies.

H3: In collectivist cultures, there is a positive relationship between the relationship of leadership style and job satisfaction about the level of organizational commitment in service companies.

\section{Methodology}

This study was quantitative, deductive, post-positivist, and transversal. Correlated the variables in companies in the service sector in Ecuador. We worked with 386 valid answers, being valid to apply the SEM method to analyze the data using SPSS and AMOS, the method of structural equations has been used in previous studies (Long, Yong y Chuen, 2016; Shurbagi, 2014; Zahari y Shurbagi, 2012; Chen, Lyu, Li, Zhou y Li, 2000).

Participants' goodwill was assumed as well as their condition to understand and answer the surveys based on the truth properly; It is also assumed that the performance of companies is affected by the leadership style and that companies with a better level of commitment get better performance (Kuo, 2013; Anari, 2012).

The sample was non-probabilistic and convenience. The study was limited to companies in the service sector of the city of Guayaquil, Ecuador. We sought to obtain a representative sample of types of services, obtaining results from health companies, technological services, tourism, industrial automation, education, among others. Three hundred eighty-six valid responses were obtained out of a total of 405 sent. We worked with a total of 27 companies in the services sector, and 15 employees of each were applied to people of middle management to reduce the risk of bias in the responses.

Three questionnaires were used for tools for information gathering, (a) the multifactorial leadership questionnaire (Avolio, Bass y Jung, 1999); (b) the three-dimensional organizational commitment questionnaire (Jha y Pandey, 2015); and (c) the job satisfaction questionnaire (Spector, 1997), all three applied at the same time. The three instruments have been widely used, translated into Spanish by their authors and validated in previous studies (Alonso, Saboya y Guirado, 2010; Bartram y Casimir, 2007; Xirasagar, 2008; Yousaf, Sanders y Abbas, 2015; Zayas-Ortiz, Rosario, 
Marquez y Gruñeiro, 2015). The three surveys are made up of 5-point Likerd scales, except for the job satisfaction score of 6 ; they have been validated presenting significant values using cron Bach alpha (Long, Yong y Chuen, 2016; Zahari y Shurbagi, 2012; Chen, Lyu, Li, Zhou y Li, 2000; Gunlu, aksarayli y Sahin, 2010; Komari y Djafar, 2013). A confirmatory factor analysis was performed to establish the convergent and divergent validity of the constructs.

The analysis unit of this study was the organizations. The surveys were carried out in the workplaces of the participants. The principles of confidentiality were maintained, and all the participations were voluntary, being informed of the participation in the study. The data were treated with the SPSS in version 24 and its AMOS application, which are the most used for studies of this type. All the variables of the study are latent or unobservable, which is why a multivariate analysis is carried out through structural equations, which allows us to observe different relationships at the same time, allow us to work with ordinal scales such as Likert's and see the relationships between variables, some previous studies that correlated these constructs used this methodology Cupani, 2012; Farzaneh, Farashah y Kazemi, 2014; Kuo, 2013; Manzano, 2017; Michel R. y Michel C., 2012; Moon, Hur, Ko, Kim y Yoon, 2014; Ruiz, 2010; Thamrin, 2012).

\section{Results}

Three hundred eighty-six valid responses were obtained, $56.7 \%$ were women, $43.3 \%$ men, $53.7 \%$ have the undergraduate academic preparation, and the difference with postgraduate studies. $71.8 \%$ have 1 to 7 years of permanence in the company. More than $50 \%$ of the participants are dedicated to the administrative area. Concerning the reliability of the scales of the constructs, it was used using Cronbach's alpha, according to Ajzen (2002), for a scale to be considered reliable, a result greater than or equal to 0.7 must be obtained; values less than 0.5 are not considered acceptable, in the following table 1 we can observe each construct, its dimensions, and results (Ajzen, 2006). 


\section{Table 1}

Reliability of the scales of each construct

\begin{tabular}{|c|c|c|c|}
\hline Construct & Subconstructs & $\begin{array}{l}\text { The Alpha of } \\
\text { Cronbach }\end{array}$ & $\begin{array}{c}\text { Number of } \\
\text { Items }\end{array}$ \\
\hline \multirow{6}{*}{$\begin{array}{l}\text { Transformational } \\
\text { Leadership }\end{array}$} & & 0.919 & 20 \\
\hline & Idealized influence - & 0.70 & 4 \\
\hline & $\begin{array}{c}\text { Attributes } \\
\text { Idealized Influence } \\
\text { (Behavior) }\end{array}$ & 0.6 & 4 \\
\hline & Inspirational Motivation & 0.805 & 4 \\
\hline & Intellectual Stimulation & 0.615 & 4 \\
\hline & Individualized Consideration & 0.7 & 4 \\
\hline \multirow[t]{4}{*}{ Transactional Leadership } & & 0.7 & \\
\hline & Contingent Reward & 0.7 & 4 \\
\hline & $\begin{array}{l}\text { Management by Active } \\
\text { Exception }\end{array}$ & 0.627 & 4 \\
\hline & $\begin{array}{l}\text { Passive Exception } \\
\text { Management }\end{array}$ & 0.70 & 4 \\
\hline \multirow[t]{10}{*}{ Work Satisfaction } & & 0.774 & 36 \\
\hline & Satisfaction with Payment & 0.6 & 4 \\
\hline & Promotion & 0.58 & 4 \\
\hline & Supervision & 0.656 & 4 \\
\hline & Benefits & 0.624 & 4 \\
\hline & Contingent Rewards & 0.674 & 4 \\
\hline & Operating conditions & 0.50 & 4 \\
\hline & Coworkers & 0.56 & 4 \\
\hline & Nature of work & 0.7 & 4 \\
\hline & Conunication & 0.69 & 4 \\
\hline \multirow{4}{*}{$\begin{array}{l}\text { Organizational } \\
\text { Commitment }\end{array}$} & & 0.914 & 18 \\
\hline & Affective Commitment & 0.86 & 7 \\
\hline & Commitment to Continuity & 0.772 & 5 \\
\hline & Regulatory Commitment & 0.81 & 6 \\
\hline
\end{tabular}

All the scales obtained an acceptable result of reliability; after this, the proposed model is analyzed, being able to observe the effects that the latent variables have between them, characteristic of a structural model. According to Chion y Charles (2016) the criteria that identify the model are: (a) one of the paths of each variable must be restricted to a value of one on the measurement scale, and (b) the links of the errors of the observable and latent variables are restricted to the value of one. After the model was identified, it was adjusted through (a) the Chi-square test (with p-value> 0.20); (b) of the residual index of the standardized mean square root (SRMR), (c) 
comparative adjustment index (CFI) and (d) the mean square root index of the approximation error (RMSEA). Figure 2 shows the simplified model:

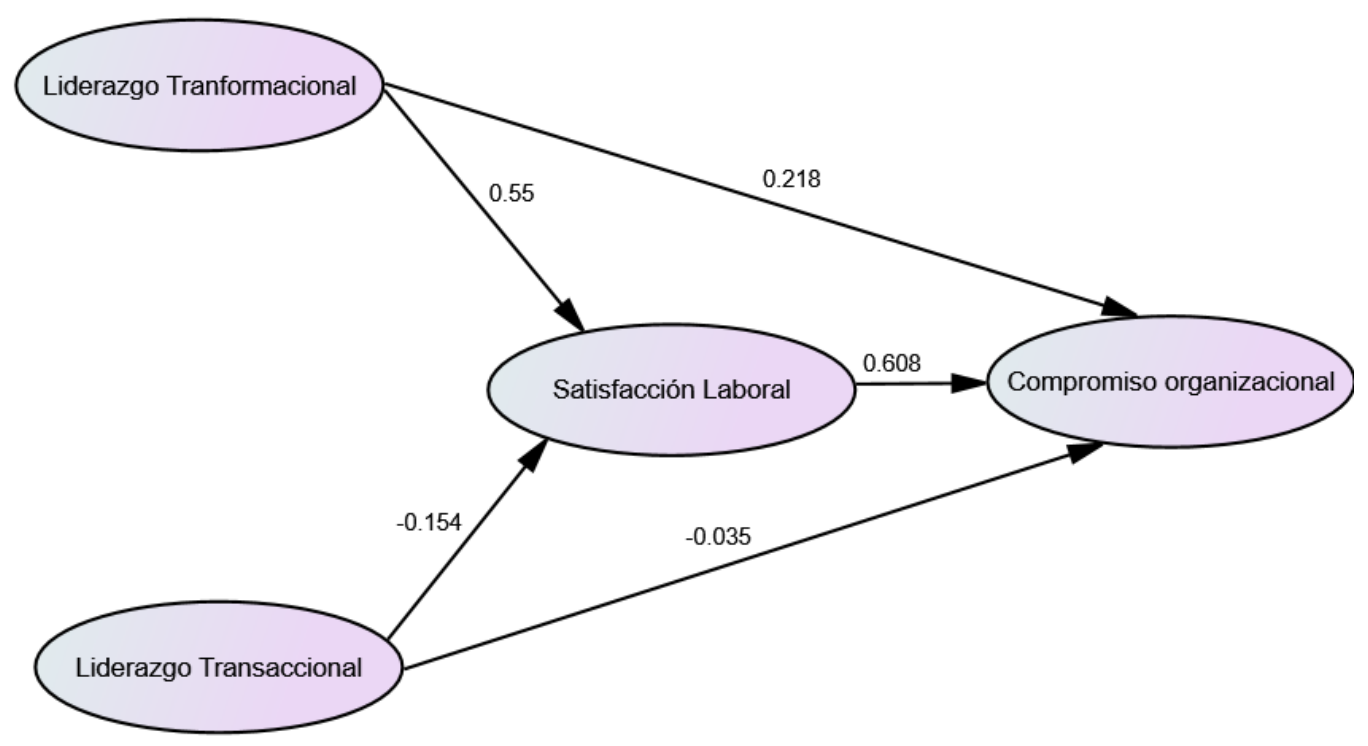

Figure 2. Simplified proposed model

\section{Table 2}

Structural Model Adjustment Indices

\begin{tabular}{ccc}
\hline Index & Value & Acceptance Level \\
\hline Chi-cuadrado & 9255.29 & $\mathrm{P}<0.00$ \\
Gl & 3543 & \\
SRMR & 0.045 & $\leq 0.05$ \\
CFI & 0.973 & $\geq 0.95$ \\
RMSEA & 0.006 & $\leq 0.06$ \\
CMIN/DF & 2.612 & $<5$ \\
\hline
\end{tabular}

All indexes are accepted according to the results obtained, which allows concluding that the model has a good data fit. As the chi-square index is sensitive to the sample size, it must be evaluated through the indices mentioned above. Convergent validity was assessed through the analysis of the significance of the regression estimates between each observable variable with each latent variable to which they correspond. Divergent validity was assessed by restricting the correlation parameter between two latent variables to 1 and testing chi-square differences between the restricted model and the unrestricted model. Pairs made the tests of constructs at the same time, 
and the two validity criteria were met in the model. To test these hypotheses, the estimated regression weights between each of the constructs were analysed (Table 3).

The results show that there is a positive and significant relationship between Transformational Leadership and Labor Satisfaction (0.552; p-value $<0.05)$, which allows accepting the $\mathrm{H} 2$ research hypothesis. However, the relationship between transactional leadership and job satisfaction is negative, although significant $(-0.154$; $\mathrm{p}$-value $<0.05)$, leading to the rejection of the $\mathrm{H} 1$ hypothesis. On the other hand, the relationship between job satisfaction and organizational commitment is positive and significant $(0.608$; $\mathrm{p}$-value $<0.05)$, as well as the relationship between transformational leadership and organizational commitment $(0.218$; $p$-value $<0.05)$. However, the relationship between transactional leadership and organizational commitment is neither positive nor significant (-0.035; p-value $>0.05)$, which leads to partially accept the $\mathrm{H} 3$ research hypothesis since there is only a relationship only of the transformational leadership style and job satisfaction on the level of organizational commitment.

Table 3

Regression weights of the structural model leadership styles and knowledge exchange

\begin{tabular}{ccccccc}
\hline & Relation & Estimate & $\begin{array}{c}\text { Standardized } \\
\text { Estimate }\end{array}$ & SE & $\mathrm{p}$ \\
\hline Work satisfaction & $<-$ & $\begin{array}{c}\text { Transformational } \\
\text { Leadership }\end{array}$ & 1.505 & 0.552 & 0.159 & .000 \\
Work satisfaction & $<-$ & $\begin{array}{c}\text { Transactional } \\
\text { Leadership }\end{array}$ & -0.419 & -0.154 & 0.181 & .020 \\
$\begin{array}{c}\text { Organizational } \\
\text { Commitment }\end{array}$ & $<-$ & $\begin{array}{c}\text { Transformational } \\
\text { Leadership }\end{array}$ & 0.746 & 0.218 & 0.173 & .000 \\
$\begin{array}{c}\text { Organizational } \\
\text { Commitment } \\
\text { Organizational } \\
\text { Commitment }\end{array}$ & $<-$ & $\begin{array}{c}\text { Transactional } \\
\text { Leadership } \\
\text { Work Satisfaction }\end{array}$ & -0.120 & -0.035 & 0.026 & .210 \\
\hline
\end{tabular}

\section{Discussion}

Statistically, the leadership style and job satisfaction influence the organizational commitment of service companies in Guayaquil. The relationship between leadership styles and organizational commitment are mediated by job satisfaction; consequently, it coincides with Shim, Jo and Hoover (2015) because they explored the relationship between transformational leadership 
and organizational commitment. Besides, this relationship was mediated by organizational culture; therefore, people's behaviour is similar to South Korea and Ecuador; the two cultures also have a high-power distance and uncertainty avoidance level.

Collectivist cultures are positively related to the transactional leadership style and the level of job satisfaction in service companies, on the other hand, transactional leadership does not have a positive but significant relationship with job satisfaction (-0.154). In this sense, few previous studies analyze the relationship between the variables of leadership styles, job satisfaction and organizational commitment that include the transactional leadership style, which is why it was merited to include them in this study, to understand that differences could be found in Ecuador in the results due to cultural factors. It should be noted that in the previous study carried out in Pakistan (Hussain Haider \& Riaz, 2010) they showed that there is a culture similar to that of Ecuador, it was also found that transactional leadership has a significant relationship with job success (0.628), unlike than transformational leadership with career satisfaction (0.545). Finding that the relationship between transactional leadership style and job satisfaction is significant but negative, it is suggested in subsequent studies to analyze only one type of service company in order to discover the positive relationship between transactional leadership style and job satisfaction. Consequently, the results harmonize with the Ali, AYS, Sidow, MA and Guleid, H.S (2013) because they studied the relationship between the two leadership styles (transformational and transactional) and job satisfaction, showing that the two have a significant and positive relationship $(0.574)$ and $(0.178)$ respectively.

There is a positive relationship between the transformational leadership style and the level of job satisfaction in service companies; this hypothesis was confirmed according to the results (0.55). Therefore, it agrees with Omar and FauziHussin (2013). They analyzed with the support of a structural equations model the relationship between the transformational leadership style and job satisfaction, in a sample of 100 people from academic institutions in Malaysia, where it was shown that the culture is also similar to the Ecuadorian characteristics according to the Hofstede model. In this work, each component of transformational leadership was related to job satisfaction, finding that intellectual stimulation (0.548) would have the most significant relationship with satisfaction, while individualized consideration is the dimension with the least relationship with satisfaction (-0.510), in the In the present work, it was found that individualized consideration (0.733) and idealized influence $(0.680)$ would be the dimensions with the most 
significant influence on job satisfaction, no dimension gave a negative result, intellectual stimulation obtained a result of 0.573 , also significant, among the conclusions that were defined in this work, they declared that the leader from the perspective of the administration or the direction is one of the most essential sources or agents of change, the companies then must worry about developing their bosses or managers to allow them to become leaders generating satisfaction in their employees in order to achieve the common objectives of the organization (Omar \& FausiHussim, 2013). These data coincide with those obtained in the present study.

The H3 of this study defined that: in collectivist cultures, there is a positive relationship between the relationship of leadership style and job satisfaction on the level of organizational commitment in service companies, this was partially demonstrated because two leadership styles, with the transformational leadership style the hypothesis confirms the relationship between leadership style and job satisfaction has a positive and significant relationship with organizational commitment (0.608). In previous studies analyzed, the results coincided with Shurbagi (2014) because it related transformational leadership with job satisfaction and its effect with organizational commitment, in the oil industry, a stratified sample correlation study analyzed using SPSS. The tools widely used and validated in other studies of this type were used: Cronbach's Alpha coefficient MLQ (0.92), TCOCQ (0.74) and JSS (0.82). The empirical results indicated that organizational commitment affects the relationship between transformational leadership style and job satisfaction, while the relationship between transformational leadership style, job satisfaction and organizational commitment was a significant positive relationship in the oil sector in Libya. A positive relationship was found between the variables and an effect of organizational commitment in the relationship between transformational leadership and job satisfaction.

It also agrees with Thamrin (2012) because it analyzed transformational leadership's influence on organizational commitment and job satisfaction in employee performance. This quantitative study also used a structural equation model for its analysis, obtaining the following results:

1. Transformational leadership would have a significant effect on organizational commitment.

2. The transformational leadership style has a positive influence on the performance of employees.

3. The transformational leadership style does not have a positive influence on job satisfaction. 
4. Organizational commitment has a positive influence on employee satisfaction as well as on their performance.

5. Job satisfaction has a positive influence on employee performance.

According to Hofstede's theory, this study was conducted in Indonesia; this country's national culture is very similar to that of Ecuador. The only different result that was obtained in this study compared to the present work is the relationship between the transformational leadership style and job satisfaction, whose result is 0.173 not significant, this result coincided with previous studies analyzed by Thamrin that stated that it is necessary worker dissatisfaction for the use of transformational leadership. In contrast, the results reflect a significant 0.55 relationship between transformational leadership and job satisfaction in this study. In the conclusions of Thamrin's (2012) work, he concluded that transformational leadership could be used to generate organizational commitment in the members of the organization and thus improve the performance of employees.

It also agrees with C.H. Chan and Mak (2014) because they sought to measure the relationship between transformational leadership and organizational commitment, introducing the variable pride analyzed from the follower's point of view, feeling proud of being a follower of a particular leader. This study analyzed two of the three dimensions of organizational commitment, normative and affective, finding that transformational leadership has a significant and positive effect with these two dimensions of organizational commitment, mediated by the pride of being a follower of a leader, it was found a positive relationship between pride in being a follower of a particular leader and affective and normative commitment. It was concluded in this study that pride in being a follower has a mediating effect between leadership style and organizational commitment.

At the same time, it agrees with Dinc (2017) in view that it analyzed the impact of the components of organizational commitment on job satisfaction and performance at work. An analysis of factors and a study of the relationship and correlation between the variables were carried out; 437 valid responses were analyzed, finding that affective and normative commitment affect job satisfaction. The study concluded that companies could improve worker performance through job satisfaction levels; this work was done in Bosnia. Regression analysis was used for data management. 
Likewise, the results coincide with a study carried out in the United Arab Emirates (RAK) because it was based on the relationship between organizational commitment, job satisfaction and attitudes towards organizational change, this work concluded that the different dimensions of job satisfaction have a significant effect on organizational commitment, also found that the dimensions of organizational commitment affect the dimensions of organizational change. The author of this study considers his discoveries relevant because companies can have about managing changes in organizations from organizational commitment levels. Quantitative study with 352 valid responses, Cronbach's Alpha, was used to analyze the variables' consistency and confirmatory factor analysis for the relationship to be studied (Yousef, 2017).

García-Almeida, Fernández Monroy and Saá-Pérez (2015) analyzed the dimensions of job satisfaction that could be considered more decisive to achieve organizational commitment in the hotel industry of Gran Canaria, Spain. This study was carried out in a sample of 760 employees from different hotels in the area finding that the importance of work, working conditions, direct rewards, the relationship with managers and the policies of the human resources department are the most critical dimensions to develop organizational commitment in this type of company.

Bruno Fabi, Richard Lacoursiere and Louis Raymond (2015) conducted a study to understand the influence of high-performance work systems on job satisfaction, organizational commitment, and the intention to leave the company. This work was analyzed in Canadian culture, a country with a national culture instead of Ecuador. This study was carried out on 730 employees in different organizations; this work was also carried out under the structural equations model. However, this work did not analyze the same variables of the present investigation if it supports that the actions that are determined from the management can affect organizational commitment and job satisfaction and, consequently, the desire to leave the organization.

Another previous study analyzed the effect of organizational culture on the relationship between transformational leadership and job satisfaction in the Libyan oil sector. This work was a quantitative correlational. The data found a positive and significant relationship between the variables (Zahari and Shurbagi, 2012).

Bushra, Usman and Naveed (2011) investigated the effect of transformational leadership on job satisfaction, and organizational commitment of workers in the banking sector in Pakistan, 133 valid responses was analyzed out of a total of 200 randomly sent, using the linear regression as a method for data treatment. This study concluded that there is a positive and significant 
relationship between the variables and that companies' productivity and performance depend on the levels of satisfaction and commitment present in employees.

Limsila and Ogunlana (2008) examined how project managers' leadership styles are related to the organizational commitment of their collaborators, a study carried out in Thailand, in the construction sector with a sample of 156 people. Thailand's national culture is similar in characteristics to those of Ecuador, although it has higher levels of individualism. This study found that the transformational leadership style has a positive relationship with job performance and organizational commitment. This study included the transactional leadership style in its analysis to verify which leadership style was more effective in the research context, finding that the transformational leadership style was more effective (0.818) while the transactional leadership had less significance (0.196). This work concluded that the transformational leadership style for people in Thailand would better affect the generation of better levels of organizational commitment due to its power distance. Currently, the relationship between bosses and subordinates is less distant than in the past. Results similar to those found in the present study.

Yeh (2008) explored in his work the effects of transformational leadership, organizational culture and job satisfaction in the organizational performance of non-profit organizations in Taiwan, a country with a culture similar to that of Ecuador, in this study it was found:

1. Transformational leadership style (0.543), organizational culture (0.623) and job satisfaction (0.586) have a significant effect on the performance of organizations.

2. Job satisfaction has a mediating effect between leadership style and organizational culture.

3. Job satisfaction has a mediating effect on transformational leadership and company performance. The sample consisted of 200 participants; regression analyses were carried out, finding significant relationships between the variables according to what was indicated above, concluding that the transformational leadership style has a positive effect on the organization's performance.

In this same year, an analysis of the effect of transformational leadership, organizational culture and job satisfaction on the performance of non-profit organizations in Taiwan was carried out, finding the following results:

1. Transformational leadership, organizational culture and job satisfaction have a significant effect on the performance of companies. 
2. Job satisfaction does have a mediating effect between the transformational leadership style and performance (Kuan Chi, H., Ren Yeh, H. \& Chion Huei Y, 2008).

Concerning national culture, this work assumed the globally accepted Hofstede theory, the reviewed works with which the results are contrasted are from 16 different countries, their dimensions were revised to try to explain if the similarities or differences of the results could be due to the national culture of each country. Ecuador is a country with a collectivist culture according to the Hofstede model. Table 8 shows the values of the dimensions of the national culture of the countries that have been part of the previously analyzed studies; it is found that some of the Asian and Middle Eastern countries have cultures similar to the Ecuadorian, which could explain why the results of the different studies are similar.

According to Hofstede (2002), Ecuador is one of the least individualistic countries analyzed, which means that in this culture, people avoid conflicts to guarantee the harmony of the group in which they operate. They can show many gestures of solidarity and empathy with the members of their team, but in the same way, they can be somewhat hostile towards strangers or new to a group in order to maintain the harmony of the group.

Ecuadorian culture is also considered more masculine, which implies that present conflicts are generally resolved by allowing the strongest to win; there is great admiration for successful people. Also considered a culture with high avoidance of uncertainty, which means high stress for this cause, it is considered a continuous threat that must be fought, in this type of culture, there is a greater need for laws and rules to follow. Ecuador has a great distance from power, which means that it is a society with little equity, there are hierarchies out of necessity, people with power are considered inaccessible and with privileges (Hofstede, 2002).

The Ecuadorian national culture would not have different results from other cultures previously analyzed. According to the results obtained, the transactional leadership style that had not been included in previous studies does not have a positive relationship with job satisfaction or organizational commitment. 
Table 4

Dimensions of National Culture - Hofstede Theory

\begin{tabular}{|c|c|c|c|c|c|c|}
\hline Countries & $\begin{array}{c}\text { Individualism / } \\
\text { Collectivism }\end{array}$ & $\begin{array}{c}\text { Power } \\
\text { distance }\end{array}$ & $\begin{array}{l}\text { Masculinity/ } \\
\text { Femininity }\end{array}$ & $\begin{array}{l}\text { Avoidance of } \\
\text { uncertainty }\end{array}$ & $\begin{array}{c}\text { Long-term } \\
\text { orientation }\end{array}$ & $\begin{array}{c}\text { Indulgent } \\
\text { culture }\end{array}$ \\
\hline Ecuador & 78 & 78 & 63 & 67 & & \\
\hline Indonesia & 78 & 14 & 46 & 48 & 62 & 38 \\
\hline South Korea & 60 & 18 & 39 & 85 & 100 & 29 \\
\hline Thailand & 64 & 20 & 34 & 64 & 32 & 45 \\
\hline Canada & 39 & 80 & 52 & 48 & 36 & 68 \\
\hline China & 80 & 20 & 66 & 30 & 87 & 24 \\
\hline Hong Kong & 68 & 25 & 57 & 29 & 61 & 17 \\
\hline Libya & 80 & 38 & 52 & 68 & 23 & 34 \\
\hline Australia & 38 & 90 & 61 & 51 & 21 & 71 \\
\hline $\begin{array}{l}\text { Arab } \\
\text { Emirates }\end{array}$ & 90 & 25 & 50 & 80 & & \\
\hline Spain & 57 & 51 & 42 & 86 & 48 & 44 \\
\hline Turkey & 66 & 37 & 45 & 85 & 46 & 49 \\
\hline UK & 35 & 89 & 66 & 35 & 51 & 69 \\
\hline U.S & 40 & 91 & 62 & 46 & 26 & 68 \\
\hline Iran & 58 & 41 & 43 & 59 & 14 & 40 \\
\hline Taiwan & 58 & 17 & 45 & 69 & 93 & 49 \\
\hline Croatia & 73 & 33 & 40 & 80 & 58 & 33 \\
\hline
\end{tabular}

Source: $\underline{w w w . h o f s t e d e-i n s i g h t s . c o m}$

\section{Conclussion}

According to the results obtained, results obtained in previous studies are confirmed (Alonso et al., 2010; Anari, 2012; Bartram \& Casimir, 2007; Cuadrado \& Molero, 2002; Fabi, Lacoursière, \& Raymond, 2015; Farahani, Taghadosi, \& Behboudi, 2011; Gunlu, Aksarayli, \& Sahin Perçin, 2010; Herrera, Torres y Hutiérrez, 2019; Jernigan III et al., 2002; Komari \& Djafar, 2013; MR Campbell, 2013; Seyal \& Afzaal, 2013; Shurbagi, 2014; Singh \& Gupta, 2015; Xirasagar, 2008; Yousaf, Sanders, \& Abbas, 2015; Zahari \& Shurbagi, 2012; Zayas-Ortiz, Rosario, Marquez, \& Gruñeiro, 2015) who evaluated the influence of the transformational leadership style 
on organizational commitment or job satisfaction.

The Ecuadorian national culture would not have different results from other cultures previously analyzed. The transactional leadership style that had not been included in previous studies, according to the results obtained, does not have a positive relationship with job satisfaction or organizational commitment. Therefore, it is recommended in future research to include the type of company (public or private) to confirm if there is a difference with the results obtained in the relationship of transactional leadership and its impact on job satisfaction and organizational commitment. It could also generate a new analysis with types of specific service companies to generate comparisons according to the characteristics of the companies, understanding that an entrepreneurial services company, for example, could have different behaviors from a health services, hospitality, or computer services company.

\section{References}

Ahluwalia, A. K., \& Preet, K. (2017). The Influence of Organizational Commitment on Work Motivation: A Comparative Study of State and Private University Teachers. IUP Journal of Organizational Behavior, 16(2), 55-69. Available at SSRN: https://ssrn.com/abstract=3209248

Ajzen, I. (2006). Constructing a TpB questionnaire: conceptual and methodological considerations. Recuperadode: https://pdfs.semanticscholar.org/0574/b20bd58130dd5a96 1f1a2db10fd1fcbae95d.pdf

Al-Laymoun, M. R. (2017). The Role Of The Transformational Leadership In Upgrading The Performance Of The Five Stars Hotels Staff From The Perspective Of Hr Managers. International Journal of Information, Business and Management, 9(4), 11. Recuperado de: https://search.proquest.com/openview/a057e93c59c9441c9cf1ef2527bca1e8/1?pqorigsite $=$ gscholar $\& \mathrm{cbl}=2032142$

Ali, A. Y. S., Sidow, M. A., \& Guleid, H. S. (2013). Leadership styles and job satisfaction: empirical evidence from Mogadishu universities. European Journal of Management Sciences and Economics, 1(1), 1-10. Recuperado de: https://www.researchgate.net/publication/235731857_LEADERSHIP_STYLES_AND_J 


\section{OB_SATISFACTION_EMPIRICAL_EVIDENCE_FROM_MOGADISHU_UNIVERSI TIES}

Alonso, F. M., Saboya, P. R., \& Guirado, I. C. (2010). Liderazgo transformacional y liderazgo transaccional: un análisis de la estructura factorial del Multifactor Leadership Questionnaire (MLQ) en una muestra española. Psicothema, 22(3), 495-501. Recuperado de: http://www.psicothema.com/psicothema.asp?id=3758

Anari, N. N. (2012). Teachers: emotional intelligence, job satisfaction, and organizational commitment. Journal of Workplace Learning, 24(4), 256-269. doi:doi:10.1108/13665621211223379

Appelbaum, S. H., Louis, D., Makarenko, D., Saluja, J., Meleshko, O., \& Kulbashian, S. (2013). Participation in decision making: a case study of job satisfaction and commitment (part one). Industrial and Commercial Training, 45(4), 222-229. https://doi.org/10.1108/00197851311323510

Armandi, B., Oppedisano, J., \& Sherman, H. (2003). Leadership theory and practice: a "case" in point. Management Decision, 41(10), 1076-1088. Recuperado de: https://www.researchgate.net/publication/235275056_Leadership_theory_and_practice_a _case_in_point

Arzi, S., \& Farahbod, L. (2014). The impact of leadership style on job satisfaction: A study of Iranian Hotels. Interdisciplinary Journal Of Contemporary Research In Business, 6(3), 171. Recuperado de: https://www.semanticscholar.org/paper/The-Impact-of-LeadershipStyle-on-Job-Satisfaction\%3A-Arzi-

Farahbod/1ff06cbfc776c0cd991cef3a52fac037f4dae7b5

Avolio, B., Bass, B., \& Jung, D. (1999). Re-examining the components of transformational and transactional leadership using the Multifactor Leadership. Journal of occupational and organizational psychology, 72(4), 441-462. https://doi.org/10.1348/096317999166789

Bandura, R. \& Lyons, P. (2014). The art and science of job satisfaction: Much of it comes down to decent management practice. Human Resource Management International Digest, 22(7), 32-35. doi:10.1108/HRMID-10-2014-0141

Bartram, T., \& Casimir, G. (2007). The relationship between leadership and follower in-role performance and satisfaction with the leader: The mediating effects of empowerment and 
trust in the leader. Leadership \& Organization Development Journal, 28(1), 4-19. https://doi.org/10.1108/01437730710718218

Bass, B. (1988). The Inspirational Processes of Leadership. Journal of Management Development, 7(5), 21-31. doi:10.1108/eb051688

Bass, B. M. (1985). Leadership and performance beyond expectations: Free Press; Collier Macmillan. https://doi.org/10.1002/hrm.3930250310

Bass, B. y Avolio, B. (1994). Transformational leadership and organizational culture,» Public Administration Quarterly Spring, (17), 112-121. Recuperado de: https://www.jstor.org/stable/40862298

Bass, B. (1997). Does the transactional-transformational leadership paradigm transcend organizational and national boundaries? American psychologist, 52(2), 130-139. https://doi.org/10.1037/0003-066X.52.2.130

Bass, B. \& Avolio, B. (1990). Developing transformational leadership: 1992 and beyond. Journal of European industrial training, 14(5). doi: 10.1108/03090599010135122

Bass, B. M., Avolio, B. J., Jung, D. I., \& Berson, Y. (2003). Predicting unit performance by assessing transformational and transactional leadership. Journal of applied psychology, 88 (2), 207-218. https://doi.org/10.1037/0021-9010.88.2.207

Bejarano, M. (2018). La importancia de las empresas de servicios en el desarrollo de los países de economías emergentes. INNOVA Research Journal, 3 (3), 1-5. doi:https://doi.org/10.33890/innova.v3.n3.2018.634

Bejarano, M. A. G., \& Siu, D.R.S. (2017). La lealtad de los clientes y su relación con la lealtad de los colaboradores. INNOVA Research Journal, 2(9), 121-125. doi:https://doi.org/10.33890/innova.v2.n9.2017.477

Bejarano, M. A. G., Suárez, R.J.P., \& Vera, M.F.A (2018). La satisfacción laboral y su efecto en la satisfacción del cliente, un análisis teórico. INNOVA Research Journal, 3(8), 140 - 146. doi:10.33890/innova.v3.n8.2018.879

Bersin, J., Agarwal, D., Pelster, B., \& Schwartz, J. (2015). "Global Human Capital Trends 2015. Leading in the new world of work". In: Retrieved from Deloitte University Press: http://dupress. com/articles/employee-engagement-culture-human-capital-trends-2015. 
Bhatti, N., Maitlo, G. M., Shaikh, N., Hashmi, M. A., \& Shaikh, F. M. (2012). The impact of autocratic and democratic leadership style on job satisfaction. International Business Research, 5(2), 192. DOI: 10.5539/ibr.v5n2p192

Braun, S., Peus, C., Weisweiler, S., \& Frey, D. (2013). Transformational leadership, job satisfaction, and team performance: A multilevel mediation model of trust. The Leadership Quarterly, 24 (1), 270-283. https://doi.org/10.1016/j.leaqua.2012.11.006

Bushra, F., Usman, A., \& Naveed, A. (2011). Effect of transformational leadership on employees' job satisfaction and organizational commitment in banking sector of Lahore (Pakistan). International journal of Business and Social science, 2 (18), 261-267. Recuperado de: https://ijbssnet.com/journals/Vol_2_No_18_October_2011/31.pdf

Bycio, P., Hackett, R. D., \& Allen, J. S. (1995). Further assessments of Bass's (1985) conceptualization of transactional and transformational leadership. Journal of applied psychology, 80 (4), 468-478. https://doi.org/10.1037/0021-9010.80.4.468

Cardona, P. (2000). Transcendental leadership. Leadership \& Organization Development Journal, 21(4), 201-207. DOI: 10.1108/01437730010335445

Chen, M., Lyu, Y., Li, Y., Zhou, X., \& Li, W. (2017). The impact of high-commitment HR practices on hotel employees' proactive customer service performance. Cornell Hospitality Quarterly, 58 (1), 94-107. https://doi.org/10.1177/1938965516649053

Chib, S. (2016). Study on organizational commitment and workplace empowerment as predictors of organization citizenship behaviour. Scholedge International Journal of Management \& Development, 3(3), 63-73. DOI: 10.19085/journal.sijmd030301

Chion, S. y Charles, V. (2016). Analítica de datos para la modelación estructural. Lima: Pearson Cohen, A. (2007). Commitment before and after: An evaluation and reconceptualization of organizational commitment. Human Resource Management Review, 17 (3), 336-354. https://doi.org/10.1016/j.hrmr.2007.05.001

Cuadrado, I., \& Molero, F. (2002). Liderazgo transformacional y género: autoevaluaciones de directivos y directivas españoles [Transformational leadership and gender: Spanish managers' self-ratings]. Revista de Psicología del Trabajo y de las Organizaciones, 18, $39-55$. Recuperado de: https://www.researchgate.net/publication/258339997_Liderazgo_transformacional_y_gen ero_autoevaluaciones_de_directivos_y_directivas_espanoles 
Cupani, M. (2012). Análisis de Ecuaciones Estructurales: conceptos, etapas de desarrollo y un ejemplo de aplicación. Revista Tesis, 1 (2), 186-199. Recuperado de: https://revistas.unc.edu.ar/index.php/tesis/article/view/2884

Daude, C., \& Fernández-Arias, E. (2010). On the role of productivity and factor accumulation in economic development in Latin America and the Caribbean. Washington D.C.: InterAmerican Development Bank. Recuperado de: https://publications.iadb.org/en/publication/role-productivity-and-factor-accumulationeconomic-development-latin-america-and

El Badawy, T. A., \& Magdy, M. M. (2015). Assessing the Impact of Emotional Intelligence on Job Satisfaction: An Empirical Study on Faculty Members with Respect to Gender and Age. International Business Research, 8 (3), 67-78. DOI:10.5539/ibr.v8n3p67

Fabi, B., Lacoursière, R., \& Raymond, L. (2015). Impact of high-performance work systems on job satisfaction, organizational commitment, and intention to quit in Canadian organizations. International Journal of Manpower, 36 (5), 772-790. doi:10.1108/IJM-012014-0005

Falconí, J. (2015). Los Servicios en el Ecuador: Algunos desafíos a Corto Plazo. Paper presented at the United Nations Conference on Trade an Development, Geneva. http://unctad.org/meetings/en/Presentation/c1mem3_2015_p18_Falconi_en.pdf

Farahani, M., Taghadosi, M., \& Behboudi, M. (2011). An exploration of the relationship between transformational leadership and organizational commitment: The moderating effect of emotional intelligence: Case study in Iran. International Business Research, 4 (4), 211 217. DOI:10.5539/ibr.v4n4p211

Farzaneh, J., Farashah, A. D., \& Kazemi, M. (2014). The impact of person-job fit and personorganization fit on OCB: The mediating and moderating effects of organizational commitment and psychological empowerment. Personnel Review, 43 (5), 672-691. doi:10.1108/PR-07-2013-0118

Feinstein, A. H., Vondrasek, D., Martin, J., Ogawa, R., Dalbor, M., Stefanelli, J., . . Cannon, H. (2001). Relationships between job satisfaction and organizational commitment among restaurant employees. Journal of Hospitality, Tourism, and Leisure Science, 1 - 26. Recuperado de: https://www.semanticscholar.org/paper/Relationships-between-job- 
satisfaction-and-among-Feinstein-

Vondrasek/9445f2208d3b2042cd5fdc299363c9f396340aa6

García-Almeida, D. J., Fernández-Monroy, M., \& Saá-Pérez, D. (2015). Dimensions of employee satisfaction as determinants of organizational commitment in the hotel industry. Human Factors and Ergonomics in Manufacturing \& Service Industries, 25 (2), 153-165. https://doi.org/10.1002/hfm.20539

Gounaris, S., \& Boukis, A. (2013). The role of employee job satisfaction in strengthening customer repurchase intentions. Journal of Services Marketing, 27 (4), 322-333. doi:doi:10.1108/08876041311330799

Guerrero, M., Añazco, K., Valdivieso, R., \& Sánchez, O. (2018). Los estilos de liderazgo y su efecto en la satisfacción laboral. INNOVA Research Journal, 3 (10), 142-148. doi:https://doi.org/10.33890/innova.v3.n10.2018.908

Gunlu, E., Aksarayli, M., \& Sahin Perçin, N. (2010). Job satisfaction and organizational commitment of hotel managers in Turkey. International Journal of Contemporary Hospitality Management, 22 (5), 693-717. https://doi.org/10.1108/09596111011053819

Gyamfi, G. D. (2014). Influence of Job Stress on Job Satisfaction: Empirical Evidence from Ghana Police Service. International Business Research, 7 (9), 108-118. DOI:10.5539/ibr.v7n9p108

Herrera, J. M. F., Torres, C. E. C., \& Gutiérrez, L. C. (2019). Validación del instrumento de compromiso organizacional en México: evidencia de validez de constructo, criterio y $\begin{array}{llllll}\text { confiabilidad. Revista } & \text { de } & \text { Psicología, } & 37 & \text { (1), }\end{array}$ doi:https://doi.org/10.18800/psico.201901.001

Hofstede, G. (1983). The cultural relativity of organizational practices and theories. Journal of international business studies, 14 (2), 75-89. Recuperado de: https://www.jstor.org/stable/222593

Hussain, M., \& Riaz, A. (2010). Role of transformational and transactional leadership with job satisfaction and career satisfaction. Business and Economic Horizons, (1), 29-38. DOI: 10.15208/beh.2010.05

INEC. (2014). Directorio de Empresas y Establecimientos. Retrieved from http://www.ecuadorencifras.gob.ec/documentos/web- 
inec/Estadisticas_Economicas/DirectorioEmpresas/Empresas_2014/Principales_Resultad os_DIEE_2014.pdf

Jain, P. (2016). The influence of transformational leadership and emotional intelligence on organizational commitment. Journal of Commerce and Management Thought, 7 (3), 586. DOI: 10.5958/0976-478X.2016.00033.1

Jernigan III, I., Beggs, J. M., \& Kohut, G. F. (2002). Dimensions of work satisfaction as predictors of commitment type. Journal of Managerial Psychology, 17 (7), 564-579. DOI: $10.1108 / 02683940210444030$

Jha, J. K., \& Pandey, J. (2015). Linking ethical positions and organizational commitment: The mediating role of job satisfaction. South Asian Journal of Management, 22 (4), 63-84. Recuperado de: https://www.researchgate.net/publication/315769364_LINKING_ETHICAL_POSITION S_AND_ORGANIZATIONAL_COMMITMENT_THE_MEDIATING_ROLE_OF_JOB _SATISFACTION

Karim, F., \& Rehman, O. (2012). Impact of job satisfaction, perceived organizational justice and employee empowerment on organizational commitment in semi-government organizations of Pakistan. Journal of Business Studies Quarterly, 3 (4), 92-104. Recuperado de: https://pdfs.semanticscholar.org/2de3/55d25be5a57d7591fb8670e6ac8a6dba9de4.pdf

Keller, R. T. (2006). Transformational leadership, initiating structure, and substitutes for leadership: a longitudinal study of research and development project team performance. Journal of applied psychology, 91(1), 202-210. DOI: 10.1037/0021-9010.91.1.202

Khalilzadeh, J., Chiappa, G. D., Jafari, J., \& Borujeni, H. Z. (2013). Methodological approaches to job satisfaction measurement in hospitality firms. International Journal of Contemporary Hospitality Management, 25(6), 865-882. doi:10.1108/IJCHM-05-20120067. https://doi.org/10.1108/IJCHM-05-2012-0067

Komari, N., \& Djafar, F. (2013). Work Ethics, Work Satisfaction and Organizational Commitment at the Sharia Bank, Indonesia. International Business Research, 6 (12), 107-117. DOI: 10.5539/ibr.v6n12p107

Kuo, Y. (2013). Organizational commitment in an intense competition environment. Industrial Management \& Data Systems, 113 (1), 39-56. doi:doi:10.1108/02635571311289656 
Locke, E. A. (1976). The nature and causes of job satisfaction. Handbook of industrial and organizational psychology, 1, 1297-1343. Recuperdo de: https://www.researchgate.net/publication/238742406_The_Nature_and_Causes_of_Job_ Satisfaction

Long, C. S., Yong, L. Z., \& Chuen, T. W. (2016). Analysis of the relationship between leadership styles and affective organizational commitment. Int J Manag Account Econ, 3, 572-598. Recuperado de: http://www.ijmae.com/article_115522_9e6ce9b72c227d44843959921354e604.pdf

Maamari, B. E. (2014). Changing management history, gender moderating pay to job satisfaction for IS users. Journal of Management History, 20(3), 311-332 doi:10.1108/JMH-01-20140007

Mahanta, M. (2012). Personal characteristics and job satisfaction as predictors of organizational commitment: An empirical investigation. South Asian Journal of Management, 19 (4), 45. Recuperado de: https://search.proquest.com/openview/3beea62b7d84fbfa216cd0528794fd78/1?pqorigsite $=$ gscholar $\& \mathrm{cbl}=46967$

Manzano, A. (2017). Introducción a los modelos de ecuaciones estructurales. Investigación en Investigación Médica, 7 (25), 67-72. https://doi.org/10.1016/j.riem.2017.11.002

Mathieu, J. E., \& Zajac, D. M. (1990). A review and meta-analysis of the antecedents, correlates, and consequences of organizational commitment. Psychological bulletin, 108 (2), 171-194. DOI: 10.1037//0033-2909.108.2.171

Meyer, J. P., \& Allen, N. J. (1991). A three-component conceptualization of organizational commitment. Human resource management review, 1 (1), 61-89. https://doi.org/10.1016/1053-4822(91)90011-Z

Meyer, J. P., \& Herscovitch, L. (2001). Commitment in the workplace: Toward a general model. Human resource management review, 11 (3), 299-326. https://doi.org/10.1016/S10534822(00)00053-X

Meyer, J. P., Stanley, D. J., Herscovitch, L., \& Topolnytsky, L. (2002). Affective, continuance, and normative commitment to the organization: A meta-analysis of antecedents, correlates, and consequences. Journal of vocational behavior, 61 (1), 20-52. Retrieved from http://www.sciencedirect.com/science/article/pii/S0001879101918421 
Michel, R. D. J., \& Michel, C. E. J. (2012). Faculty satisfaction and work-family enrichment: The moderating effect of human resource flexibility. Procedia-Social and Behavioral Sciences, 46, 5168-5172. https://doi.org/10.1016/j.sbspro.2012.06.402

Moon, T.-W., Hur, W.-M., Ko, S.-H., Kim, J.-W., \& Yoon, S.-W. (2014). Bridging corporate social responsibility and compassion at work: Relations to organizational justice and affective organizational commitment. Career Development International, 19 (1), 49-72. doi:doi:10.1108/CDI-05-2013-0060

MR Campbell, S. (2013). The applicability of commitment models in a unionized professional workplace. International Journal of Organizational Analysis, 21(4), 488-503. https://doi.org/10.1108/IJOA-06-2012-0591

Nawaz, M. \& Bodla, M. (2010). Comparative study of full range leadership model among faculty members in public and private sector higher education institutes and universities. International Journal of Business and Management, 5 (4), 208 - 214. DOI:10.5539/ijbm.v5n4p208

Ordoñez, J. A. (2011). Informe de Coyntura Económica $\mathrm{N}^{\mathrm{o}}$ 7. Retrieved from http://www.utpl.edu.ec/comunicacion/wp-content/uploads/2012/12/utpl-Informe-decoyuntura-economica-N-7-ano-2011.pdf

Pantouvakis, A., \& Bouranta, N. (2013a). The interrelationship between service features, job satisfaction and customer satisfaction: Evidence from the transport sector. The TQM Journal, 25(2), 186-201. doi:doi:10.1108/17542731311299618

Pantouvakis, A., \& Bouranta, N. (2013b). The link between organizational learning culture and customer satisfaction: Confirming relationship and exploring moderating effect. The Learning Organization, 20 (1), 48-64. doi:10.1108/09696471311288528

Politis, J. D. (2002). Transformational and transactional leadership enabling (disabling) knowledge acquisition of self-managed teams: the consequences for performance. Leadership \& Organization Development Journal, $23 \quad$ 186-197. https://doi.org/10.1108/01437730210429052

Pujol-Cols, L. J., \& Dabos, G. E. (2018). Satisfacción laboral: una revisión de la literatura acerca de sus principales determinantes. Estudios Gerenciales, 34 (146), 3-18. doi:10.18046/j.estger.2018.146.2809 
Quintana, T. A., Park, S., \& Cabrera, Y. A. (2015). Assessing the effects of leadership styles on employees' outcomes in international luxury hotels. Journal of Business ethics, 129 (2), 469-489. DOI: 10.1007/s10551-014-2170-3

Robbins, S., Judge, T. A., Millett, B., \& Boyle, M. (2013). Organizational behaviour: Pearson Higher Education AU

Ruiz, M. A. P., Antonio; San Martin, Rafael (2010). Modelos de ecuaciones estructurales. Papeles del psicólogo, 31(1), 34-45. Recuperado de: http://www.papelesdelpsicologo.es/pdf/1794.pdf

Saner, T., \& Sadikoglu, G. (2016). Gender differences in job satisfaction in 5 star hotels of north Cyprus: descriptive analysis. Procedia Computer Science, 102, 359-364. https://doi.org/10.1016/j.procs.2016.09.412

Savery, L. K., \& Syme, P. D. (1996). Organizational commitment and hospital pharmacists. Journal of Management Development, 15 (1), 14-22 doi:doi:10.1108/02621719610107773

Seyal, A. H., \& Afzaal, T. (2013). An investigation of relationship among emotional intelligence, organizational commitment and job satisfaction: evidence from academics in Brunei Darussalam. International Business Research, 6 (3), 217-228. DOI:10.5539/ibr.v6n3p217

Shanker, M. (2016). Organizational Citizenship Behavior and Organizational Commitment in Indian Workforce. Journal of Psychosocial Research, 11 (2), 397. DOI: 10.1108/BPMJ02-2018-0048

Shurbagi, A. M. A. (2014). The Relationship between Transformational Leadership Style Job Satisfaction and the Effect of Organizational Commitment. International Business Research, 7(11), 126-138. DOI: 10.5539/ibr.v7n11p126

Singh, A., \& Gupta, B. (2015). Job involvement, organizational commitment, professional commitment, and team commitment: A study of generational diversity. Benchmarking: An International Journal, 22 (6), 1192-1211 doi:10.1108/BIJ-01-2014-0007

Slocum, J. \& Hellriegel, D. (2009). Principles of organizational behavior. South-Western: Cengage Learning.

Spector, P. (1985). Measurement of human service staff satisfaction: Development of the Job Satisfaction Survey. American journal of community psychology, 13(6), 693-713. https://doi.org/10.1007/BF00929796

Spector, P. (1997). Job satisfaction: Application, assessment, causes, and consequences. Sage. 
Thamrin, H. (2012). The influence of transformational leadership and organizational commitment on job satisfaction and employee performance. International Journal of Innovation, Management and Technology, 3 (5), 566-572. DOI: 10.7763/IJIMT.2012.V3.299

Van Der Westhuizen, D. W., Pacheco, G., \& Webber, D. J. (2012). Culture, participative decision making and job satisfaction. The International Journal of Human Resource Management, 23 (13), 2661-2679. https://doi.org/10.1080/09585192.2011.625967

Vetráková, M., \& Mazúchová, L. (2015). Modeling of process work motivation in hotels. Procedia Economics and Finance, 34, 508-513. https://doi.org/10.1016/S2212-5671(15)01661-5

Vigoda-Gadot, E. (2007). Leadership style, organizational politics, and employees' performance: An empirical examination of two competing models. Personnel Review, 36 (5), 661-683. https://doi.org/10.1108/00483480710773981

Vujičić, D., Jovičić, A., Lalić, D., Gagić, S., \& Cvejanov, A. (2015). The relation between job insecurity, job satisfaction and organizational commitment among employees in the tourism sector in Novi Sad. Economic and Industrial Democracy, 36 (4), 633-652. DOI: $10.1177 / 0143831 X 14527017$

Walumbwa, F. O., Lawler, J. J., \& Avolio, B. J. (2007). Leadership, individual differences, and work-related attitudes: A cross-culture investigation. Applied psychology, 56 (2), 212-230. https://doi.org/10.1111/j.1464-0597.2006.00241.X

Wang, X.-H. F., \& Howell, J. M. (2010). Exploring the dual-level effects of transformational leadership on followers. Journal of Applied Psychology, 95 (6), 1134-1143

Xirasagar, S. (2008). Transformational, transactional and laissez-faire leadership among physician executives. Journal of Health organization and management, 22 (6), 599-613. https://doi.org/10.1037/a0020754

Yaghoubipoor, A., Tee, O. P., \& Ahmed, E. M. (2013). Impact of the relationship between transformational and traditional leadership styles on Iran's automobile industry job satisfaction. World Journal of Entrepreneurship, Management and Sustainable Development, 9 (1), 14-27 doi:10.1108/20425961311315692

Yahaya, R., Ebrahim, F. A., \& Sheard, G. (2016). Leadership styles and organizational commitment: literature review. Journal of Management Development, 35(2). https://doi.org/10.1108/JMD-01-2015-0004 
Yiing, L. H., \& Ahmad, K. Z. B. (2009). The moderating effects of organizational culture on the relationships between leadership behaviour and organizational commitment and between organizational commitment and job satisfaction and performance. Leadership \& Organization Development Journal, 30(1), 53-86 doi:10.1108/01437730910927106

Yousaf, A., Sanders, K., \& Abbas, Q. (2015). Organizational/occupational commitment and organizational/occupational turnover intentions: A happy marriage? Personnel Review, 44 (4), 470-491 doi:10.1108/PR-12-2012-0203

Zahari, I. \& Shurbagi, A. (2012). The effect of organizational culture and the relationship between transformational leadership and job satisfaction in petroleum sector of Libya. International Business Research, 5 (9), 89-97. DOI:10.5539/ibr.v5n9p89

Zayas-Ortiz, M., Rosario, E., Marquez, E., \& Gruñeiro, P. C. (2015). Relationship between organizational commitments and organizational citizenship behaviour in a sample of private banking employees. International Journal of Sociology and Social Policy, 35(1/2), 91-106. doi:10.1108/IJSSP-02-2014-0010

Zhao, X. R., Ghiselli, R., Law, R., \& Ma, J. (2016). Motivating frontline employees: Role of job characteristics in work and life satisfaction. Journal of Hospitality and Tourism Management, 27, 27-38. https://doi.org/10.1016/j.jhtm.2016.01.010

Zumrah, A. \& Boyle, S. (2015). The effects of perceived organizational support and job satisfaction on transfer of training. Personnel Review, 44 (2), 236-254. doi:10.1108/PR02-2013-0029 